\title{
Progressive right ventricular dilatation after repair of tetralogy of Fallot: myth or reality? A single center evaluation by repeat cardiovascular magnetic resonance over 37 months
}

Tobias Rutz ${ }^{1}{ }^{*}$, Susanne Naumann ${ }^{2}$, Christian Meierhofer ${ }^{2}$, Stefan Martinoff ${ }^{2}$, Peter Ewert ${ }^{2}$, Heiko Stern², Sohrab Fratz ${ }^{2}$

From 18th Annual SCMR Scientific Sessions

Nice, France. 4-7 February 2015

\section{Background}

Surgical repair of tetralogy of Fallot (TOF) frequently leads to pulmonary regurgitation and right ventricular (RV) dilatation. This study assesses the rate of progression of RV dilatation over time and the impact of surgical correction with and without transannular patch repair.

\section{Methods}

Fifty-one patients underwent two cardiac magnetic resonance (CMR) exams (time between exams $37 \pm 21$ months) with determination of RV and left ventricular $(\mathrm{LV})$ volumes and pulmonary regurgitant fraction (PR). Three groups with different repair techniques were examined: transannular patch repair $(\mathrm{TA}, \mathrm{n}=22)$, subvalvular patch repair $(\mathrm{SV}, \mathrm{n}=15)$ or infundibulectomy (IN, n=14).

\section{Results}

No patient had RV outflow tract obstruction or undergone RV outflow tract intervention. TA patients were significantly younger: TA $17 \pm 10$ vs. SV $22 \pm 9$ vs. IN $28 \pm 11$ years, $\mathrm{p}=0.005$. $\mathrm{RV}$ enddiastolic volume index (RVEDVI) and PR did not change significantly in the whole group: RVEDVI: $118 \pm 23$ vs. $119 \pm 23 \mathrm{ml} / \mathrm{m}^{2}$, $\mathrm{p}=0.684$. PR: $32 \pm 11$ vs. $32 \pm 11 \%, \mathrm{p}=0.772$. There was no significant difference of RVEDVI in each group between first and last CMR: TA $120 \pm 21$ vs. $122 \pm 22 \mathrm{ml} / \mathrm{m}^{2}$,

${ }^{1}$ Service de Cardiologie, Centre Hospitalier Universitaire Laudois, Lausanne, Switzerland

Full list of author information is available at the end of the article $\mathrm{p}=0.516 ; \mathrm{SV} 112 \pm 23$ vs. $111 \pm 23 \mathrm{ml} / \mathrm{m}^{2}, \mathrm{p}=0.700 ; \mathrm{IN}$ $123 \pm 28$ vs. $123 \pm 25 \mathrm{ml} / \mathrm{m}^{2}, \mathrm{p}=0.936$.

RVEDVI at last CMR and change of RVEDVI per year did not differ between groups: TA $122 \pm 22$ vs. SV $111 \pm 23$ vs. IN $123 \pm 25 \mathrm{ml} / \mathrm{m}^{2}, \mathrm{p}=0.301$; change RVEDVI: TA $0.4 \pm 9.3$ vs. SV $-0.4 \pm 7.3$ vs. IN $-2.2 \pm 13.1 \mathrm{ml} / \mathrm{m}^{2} / \mathrm{y}$, $\mathrm{p}=0.742$.

\section{Conclusions}

There is no significant progression of RV dilatation in patients after TOF repair with moderately dilated RV during a median follow-up of 37 months. Valve sparing repair techniques, however, do not to preclude from RV dilatation.

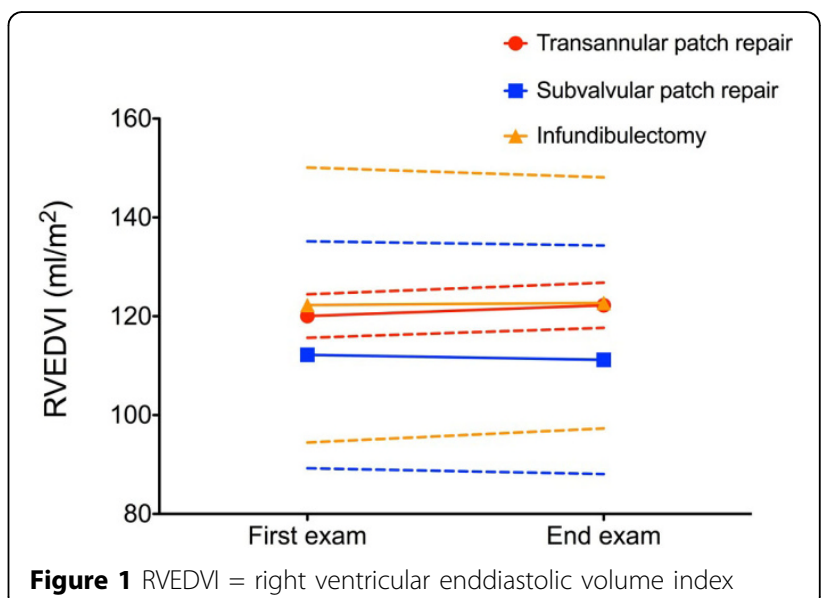




\title{
Authors' details
}

'Service de Cardiologie, Centre Hospitalier Universitaire Laudois, Lausanne,

Switzerland. ${ }^{2}$ Deutsches Herzzentrum München, Munich, Germany.

Published: 3 February 2015

\begin{abstract}
doi:10.1186/1532-429X-17-S1-P223
Cite this article as: Rutz et al:: Progressive right ventricular dilatation after repair of tetralogy of Fallot: myth or reality? A single center evaluation by repeat cardiovascular magnetic resonance over 37 months. Journal of Cardiovascular Magnetic Resonance 2015 17(Suppl 1): P223.
\end{abstract}

Submit your next manuscript to BioMed Central and take full advantage of:

- Convenient online submission

- Thorough peer review

- No space constraints or color figure charges

- Immediate publication on acceptance

- Inclusion in PubMed, CAS, Scopus and Google Scholar

- Research which is freely available for redistribution

Submit your manuscript at www.biomedcentral.com/submit 